\title{
PETA LUARAN LEMBAGA PENDIDIKAN KOMUNIKASI (Studi Pada Program Ilmu Komunikasi Universitas Padjadjaran)
}

\author{
Agus Rahmat \\ Fakultas Ilmu Komunikasi, Universitas Padjadjaran \\ Email: agusrahmat.fikom@gmail.com
}

\begin{abstract}
ABSTRAK
Kesadaran akan pentingnya sumber daya manusia yang berkualitas telah lama menjadi kesepakatan para pemimpin, yang tidak ada kesepakatan adalah konsep kualitas dari hasil pendidikan. Penelitian ini tidak untuk memperdebatkan apakah kelompok pendidikan vokasi yang lebih berkualitas atau pendidikan akademik yang lebih berkualitas. Penelitian ini lebih berpegang pada pemikiran bahwa kualitas dari sebuah pendidikan pada akhirnya bertumbu pada penerimaan luaran sebuah lembaga pendidikan termasuk perguruan tinggi oleh masyarakat pengguna, dan penerimaan luaran oleh pengguna inilah yang akan memunculkanpenilaian masyarakat mengenai tinggi atau rendah kualitas lembaga pendidikan.
\end{abstract}

Kata kunci: Sumber daya, pendidikan, luaran, pengguna, kualitas,

\section{PENDAHULUAN}

Fenomena yang muncul dala kehidupan kenegaraan menunjukan bahwa tidak sedikit negara yang memiliki kekuatan atau pengaruh dan mencapai tingkat kesejahteraan yang tinggi atau unggul bukan karena kepemilikan atas sumber daya alam yang berlimpah, melainkan karena kepemilikan atas sumber daya manusia yang berkualitas.

Kesadaran akan pentingnya sumber daya manusia yang berkualitas disadari oleh semua pemerintah termasuk pemerintah Indonesia, hal ini bisa dilihat dalam kebijakan-kebijakan yang sangat strategis. Salah satu kebijakan yang pernah dilakukan oleh pemerintah indonesia diantaranya; kebijakan terkait dengan pemerataan dan perluasan kesempatan memperoleh pendidikan; peningkatan pada semua jenjang dan jenis pendidikan; peningkatan relevansi (link atau keterkaitan untuk pendidikan dasar dan menengah umum serta kesepadanan untuk pendidikan menengah kejuruan dan tinggi); peningkatan efisiensi pengelola penyelenggaraan pendidikan pada semua jenjang dan jenisnya (Dikbud,1996).

Untuk mencapai kebijakan strategis tersebut khususnya dalam segi peningkatan kualitas baik pada tingkat dasar, menengah ataupun tinggi, departemen pendidikan dan kebudayaan memusatkan aktifitas (prioritas) pada tiga factor, yaitu: kecukupan atas sumber; mutu atas proses; dan mutu hasil atau luaran.

Pencapaian prioritas kecukupan, akan banyak berkaitan dengan jajaran birokrasi baik pada pusat maupun wilayah atau daerah, sedangkan untuk aspek mutu proses dan mutu hasil, keberhasilannya selain banyak keterkaitan dengan kebijaksanaan-kebijaksanaan birokrat baik nasional maupun wilayah, juga banyak dipengaruhi oleh instusional (lembaga/ satuan pelaksanapendidikan) dan tingkat oprasional (kegiatan), bahkan untuk faktor yang ketiga keberhasilannya banyak bertumpu pada satuan pendidikan seperti sekolah-sekolah ataupun perguruan tinggi-perguruan tinggi (PT).

Hasil penilaian dari beberapa ahli terkait dengan luaran atau lulusan menunjukan masih belum banyak memberi hasil seperti yang diharapkan.Hal ini bisa dilihat melalui gugatan ataupun penilaian negatif yang datang dari masyarakat mengenai kekurang berhasilannya pendidikan yang ada di Indonesia, baik dalam tataran tingkat nasional maupun untuk tataran satuan pelaksanaan. Contoh mengenai kurang berhasilnya satuan pelaksanaan pendidikan tersebut terdapat dalam Harian Umum Kompas tanggal 25 Mei 1999.Kesimpulan makalah Soedodjarto pada seminar nasional menuliskan bahwa "Sekolah gagal melakukan fungsi pendidikan dan mencapai pendidikan nasional".

Sesungguhnya banyak faktor yang berpengaruh terhadap gagal dan berhasilnya pendidikan pada sebuah lembaga atau satuan lembaga penyelenggara pendidikan, seperti: sumber belajar atau kurikulum, keadaan peserta didik, prosedur pengajaran, fasilitas yang ada, lingkungan pendidikan serta lain sebagainya.

Satuan pendidikan dalam melaksanakan aktivitasnya memperoleh masukan input. 
Menurut Abin Syamsudin Makmum (1996:9) masukan itu meliputi: Masukan dasar sperti manusia (peserta didik), bukan manusia; data atau fakta informasi permasalahan/tugas, cita-cita/komitmen, serta masukan instrumental yang berupa infrastruktur, dana, sarana/prasarana, dan masukan lingkungan; (trigatra: geografis, demografis dan cultural), panca gatra (politik sosial, ekonomi, hankam dan agama), dalam suatu suasana atau iklim tertentu.

Salah satu satuan unit penyelenggara pendidikan yang menjadi sorotan saat ini adalah Fakultas Ilmu Komunikasi Universitas Padjadjaran. Fakultas ini telah memperlihatkan eksistensinya berupa produktivitas lembaga yang ditunjukan dengan penghargaan enam (6) kali berturut turut sebagai The best School of Communications, versi majalah Swa.Prestasi lainnya juga ditunjukan melalui apresiasi berupa minat untuk menjadi peserta didik di fakultas ini.

Di strata pascasarjana khususnya strata magister, prestasi yang dicapainya tidak berbeda. Sebagai contoh tahun 2012 menurut Detik.Com, menempatkan pascasarjana Ilmu Komunikasi Fakultas Ilmu Komunikasi Unpad sebagai terpavorit, dan pada tahun 2013 ini Lembaga ini Fikom Unpad sebagai satu-satunya program studi lembaga ini di Indonesia yang memperoleh Akreditasi A dari Badan Akreditasi Nasonal Perguruan Tinggi (BAN-PT).

Persoalan selanjutnya adalah apakah prestasi yang dicapai lembaga pendidikan ini (Lembaga ini Fikom Unpad) juga diapresiasi tinggi oleh pengguna (user) ?

Persoalan ini dinilai penting terkait dengan penilaian kualitas pendidikan sebuah lembaga, dimana salah satu elemen yang diperhatikan menurut Contect Input Process Produck (CIPP) adalah apresiasi pengguna terhadap output dari lembaga pendidikan. Pengetahuan atas apresiasi pungguna lulusan sebuah satuan pendidikan dinilai penting dalam kaitannya sebagai sebuah evaluasi proses pendidikan di sebuah satuan penyelenggara pendidikan.

Banyak nilai guna sebuah hasil evaluasi atas output bagi sebuah lembaga penyelenggara pendidikan, selain untuk mengetahui posisi lembaga penyelenggara pendidikanjuga sebagai bahan penentu kegiatan satuan penyelenggara pendidikan di masa datang.

Atas dasar nilai penting evaluasi output oleh satuan penyelenggara pendidikan ini, maka dinilai perlu untuk dilakukan penelitian ini.

\section{Masalah Penelitian}

Berlandaspadalatarbelakangsebagaimana di deskripsikan, maka rumusan masalah dalam penelitian ini adalah : "Bagaimana apresiasi pengguna terhadap luaranLembaga ini ? “

Guna menjawab permasalahan dalam penelitian ini secara tuntas, dibutuhkan data dari berbagai aspek, oleh karena itu rumusan masalah dari penelitian ini dipandang perlu untuk lebih di urai sesuai dengan aspek yang biasa diapresiasi pengguna dari sebuah luaran perguruan tinggi, yang selanjutnya aspek-aspek ini terurai menjadi pertanyaan penelitian, yaitu: bagaimana persepsi penggunaluaran mengenai kemampuan Integritas (Etika dan Moral) luaran lembaga ini?; bagaimana persepsi pengguna luaran mengenai profesionalisme luaran lembaga ini ?; bagaimana persepsi mengenai keahlian berbahasa asing luaran Lembaga ini ?; bagaimana persepsi

Penggunaan teknologi informasi lembaga ini?; bagaimana persepsi pengguna luaran mengenai kemampuan berkomunikasi lembaga ini?; bagaimana persepsi pengguna luaran mengenai kemampuan bekerjasama dalam tim dari luaran lembaga ini ?; serta bagaimana persepsi pengguna luaran mengenai pengembangan diri luaran lembaga ini ?.

\section{Landasan Teoritis}

\section{Pendidikan dan Perubahan Sosial}

Green, Haines, dan Putnam yang dikutif Morse, mengidentifikasi empat jenis investasi yang akan menentukan kemajuan sebuah masyarakat, yaitu ; modal manusia, modal social dan modal kewarganegaraan serta modal fisik. Secara lengkap pemikiran Putnam

Diantara faktor tersebut, faktor manusia dinilai sebagai faktor yang paling dominan. Dengan kata lain, investasi yang paling penting bagi kemajuan sebuahmasyarakat dimasa datang tidak lain adalah modal manusia. Sementara itu, dalam investasi sumber daya manusia tersebut, yang dinilai memilikiandil paling besar adalah pendidikan.

Pemikiran pentingnya pendidikan bagi kehidupan seseorang, masyarakat ataupun negara diperkuat oleh berbagai hasil penelitian maupun pemikiran. Sebagai contoh pemikiran yang dikemukakan Inkeles dalam Rahmat 
(2008) bahwa "lamanya seseorang mengenyam pendidikan sekolah merupakan prediktor yang konsisten dan powerful terhadap sikap, nilainilai, dan perilaku seseorang". Sementara itu, Parson masih dalam Rahmat (2008) berpendapat bahwa "Pendidikan berfungsi untuk perubahan sosial dan untuk pusat inovasi”. Sedangkan ahli ekonomi terutama dari pendukung teori human kapital seperti Fagerlin dan Saha dalam Rahmat (2008) memandang pendidikan sebagai investasi jangka panjang yang memerlukan biaya mahal untuk menghasilkan keuntungan besar pada masa depan.

Berdasarkan berbagai pemikiran dan hasil penelitian sebagai mana diungkap maka bisa ditarik kesimpulan bahwa, jalan keluar untuk membebaskan warga masyarakat dari kebodohan dan kemiskinan tidak lain kecuali melalui pendidikan, atau bisa juga diartikan bahwa kemajuan suatu negara hanya akan terjadi apabila pendidikan dikembangkan bagi seluruh lapisan masyarakat, termasuk ketika negara berkeinginan untuk memperbaiki nasib atau mencapai kemajuan ekonomi masyarakat miskin. Berkaitan dengan peran pendidikan, secara tegas Bramel dalam Rahmat (2008) menyatakan, "Education as power means competent and strong enough to enable us, the majority of people, to decide what kind of a world we want and how to achieve that kind world". Dengan kata lain, pendidikan merupakan kekuatan, yang berwenang dan cukup mampu menentukan dunia seperti apa yang kita inginkan. Secara singkat pemikiran para pakar sebagaimana diungkap bisa dikesimpulkan bahwa pendidikan merupakan wahana bagi pengembangan manusia.

Pendidikan sebagai upaya pengembangan manusia secara konsep menurut Satori bisa dibedakan dengan pengembangan Sumber Daya Manusia. Pengembangan manusia dibagi dalam dua segi, yaitu : pertama ikhtiar mengembangkan kemampuan (capability) manusia seperti peningkatan kesehatan, pendidikan dan keterampilan; dan kedua, mengembangkan penggunaan kemampuan dalam rangka meningkatkan produktivitas, kesantaian hidup, kegiatan sosial, budaya dan politik.(Hikmat dalam Rahmat, 2008).

Konsep lainnya adalah pengembangan Sumber Daya Manusia (SDM), dalam konsep yang kedua ini, manusia dipandang semata- mata hanya faktor produksi dalam proses ekonomi. Jadi pengembangan SDMcenderung dikaitkan dengan kedudukanya sebagai faktor produksi semata. Ini berarti pembicaraan mengenai pengembangan manusia selalu dikaitkan dengan investasi baik bagi individu, organisasi maupun masyarakat.

\section{Pendidikan Sebagai Investasi}

Bagi para penganut pemikiran bahwa Sumber Daya Manusia (SDM) sebagai investasi atau yang memandang manusia sebagai faktor produksi, jelas akan memiliki konsekuensi berkaitan dengan persoalan nilai balik (rate return) dari aktivitas pengembangan SDM.

Berkaitan dengan rate return dari pengembangan sumber daya manusia dalam bidang pendidikan, Satori berpendapat bahwa " Hasil pendidikan diukur dari segi nilai tambah yang dirasakan oleh individu (private benefit) dan masyarakat atau bangsa (social benefit) dalam meningkatkan mutu kehidupannya."

Selanjutnya Satori juga berpendapat bahwa "konsep pendidikan sebagai investasi dimaksudkan sebagai proses penanaman modal dalam usaha pengembangan potensi manusia. Potensi yang dikembangkan tersebut pada gilirannya merupakan nilai-nilai dan kemampuan yang diperlukan bagi peningkatan mutu hidup manusia".

Rate return hasil pendidikan bagi kemajuan masyakat mencakup atas dua hal, yaitu nilai ekonomis dan non ekonomis. Nilai ekonomis dikaitkan dengan lama dan kualitas dari pendidikan dihubungkan dengan pertambahan nilai produktivitas. Dalam pendekatan ini dikembangkan beberapa pen-dekatan, dua diantaranya :

- Pendekatan korelasi; merupakan pendekatan yang "mencari hubungan tingkat perkembangan pendidikan dengan tingkat pertumbuhan ekonomi." Pendekatan ini nampaknya telah banyak dikaji mulai dari level sebuah negara, bahkan kajian atas pendekatan ini telah banyak dilakukan baik oleh individu, nasional maupun internasional. Penelitian Sofyan dan Anwar dalam Iriantara (2007) menyimpulkan bahwa di desa-desa IDT di Sulawesi Tenggara menunjukan bahwa hubungan antara pendidikan dengan kemajuan desa pantai sebesar 0,65 dan untuk desa pedalaman sebesar 0,21 . 
- Pendekatan atas besarnya keuntungan; merupakan pendekatan yang mengkaji penghasilan orang berpendidikan berasal dari investasi dalam pendidikan, (membandingkan orang yang berpendidikan dengan yang pendidikannya kurang). Untuk melakukan ini caranya adalah dengan analisa costbenefit, yaitu dinyatakan sebagai prosentase keuntungan investasi dalam pendidikan untuk perorangan maupun untuk masyarakat secara keseluruhan. Contoh dari kajian ini adalah kajian dari Psacharopoulos yang dikutif Djoyonegoro dalam Mimbar Pendidikan No.4. Kajian ini melaporkan, social rate of return pendidikan sekolah dasar mencapai $18,4 \%$, sementara untuk sekolah menengah mencapai $13,1 \%$ dan social rate return perguruan tinggi mencapai $10,9 \%$. Sementara itu, keuntungan investasi pendidikan secara ekonomi bagi individu untuk sekolah dasar mencapai $29,1 \%$, untuk sekolah menengah mencapai $18,1 \%$, dan untuk perguruan tinggi mencapai $20,3 \%$.

Pemikiran bahwa pendidikan sebagai investasi merupakan pendekatan yang paling banyak di pegang masyarakat. Konsekuensinya, orang tua, ataupun lembaga yang mengirimkan anak ataupun pegawainya untuk mengikuti pendidikan di perguruan tinggi pada akhirnya akan melakukan evaluasi terhadap apa yang ia investasikan tersebut. Hasil evaluasi yang dilakukan investor pendidikan ini biasanya dilakukan lebih pada outcome pendidikan tinggi dibanding pada output.

\section{Kualitas Pendidikan}

Selama perjalananya, kualitas Pendidikan seringkali menjadi isu sentral, paling tidak menjadi hal yang secara terus menerus dikritisi oleh berbagai kalangan, hal yang sama terjadi juga di jenjang pendidikan tinggi.

Mencapai kualitas pendidikan dirasakan demikian sulit, dan kesulitan ini diperparah dengan ketiadaan persamaan rumusan arti mengenaikualitas pendidikanitu sendiri, bahkan sampai ada ahli dari kelangan pendidikan sendiri yang menunjukan sikap pesimis,kondisi ini terkait dengan alasannya "akibat keragaman kebutuhan pelanggan atau pengguna luaran".

Kualitas luaran suatu perguruan tinggi lebih banyak dikaitkan dengan pengguna.
Konsekuensinya adalah, perguruan tinggi dikatakan bermutu manakala mampu meme-nuhi kebutuhan dan kepuasan pemakai/pengguna.

Djoyonegoro berpendapat bahwa kualitas atau mutu bisa dilihat dalam beberapa hal, yaitu :

1) Peserta didik menunjukan tingkat penguasaan tinggi terhadap tugas-tugas belajar (learning tasks) yang harus dikuasai sesuai dengan tujuan dan sasaran pendidikan (salah satunya dinyatakan dalam prestasi belajar/kualitas internal)

2) Hasil pendidikan sesuai dengan kebutuhan peserta didik dalam kehidupan hingga dengan belajar tadi peserta didik dapat melakukan sesuatu yang fungsional dalam kehidupannya

3) Hasil pendidikan sesuai atau relevan dengan tuntutan lingkungan khususnya dunia kerja.

Pelibatan stakeholders dalam menilai kualitas sebuah satuan penyelenggara pendidikan khususnya di perguruan tinggi, secara otomatis menunjukan bahwa pendidikan tidak akan pernah bahkan tidak boleh melepaskan diri dari lingkungannya (eksternal, stakeholders), baik pengguna ataupun orang tua/keluarga yang memasukan keluargnya ke perguruan tinggi.

Terkait dengan pendidikan sebagai investasi maka stakeholders khususnya orang tua akan melakukan evaluasi atas uang yang diinvestasikan pada pendidikan baik untuk pribadi maupun sosial.

Bagi stakeholders yang berupa keluarga, rate return biasanya dilihat dari kecepatan waktu memperoleh pekerjaan sesudah lulus dari perguruan tinggi, take home pay (gaji) yang diperoleh seseorang sesudah lulus dari sebuah perguruan tinggi. Selain hal-hal yang bersifat tangable, evaluasi stakeholder atas luaran perguruan tinggi juga bisa menyangkut halhal yang bersifat intangable seperti perubahan status keluarga di lingkungan sosialnya, dan lain sebagainya.

Hasil evaluasi stakeholders atas semua itu pada akhirnya akan bermuara pada tingkat kepuasan stakeholder mengikutsertakan anggota keluarga (anak) pada sebuah perguruan tinggi. Selanjutnya tinggi dan rendahnya apresiasi staholder ini salah satunya bisa dilihat dari keinginan stakeholder untuk memasukan 
anggota keluarganya yang lain (anak-anaknya atau adik-adiknya yang lain) pada lembaga penyelenggara pendidikan tersebut.

Bagi penyelenggara pendidikan, apresiasi dari stakeholders menjadi salah satu dasar pertimbangan dalam menentukan tujuan penyelenggaraan pendidikan di perguruan tingginya, dan selanjutnya menjadi dasar pula bagi penentuan standar penyelenggaraan pendidikan mulai dari penentuan standar masukan atau row-input, penentuan standar proses penyelenggaraan pendidikan, dan penentuan standar output atau luaran seperti apa yang dihasilkan perguruan tinggi tersebut.

\section{METODE}

Penelitian ini bertujuan memetakan persepsi pengguna luaranLembaga ini.Untuk mencapai tujuan dalam penelitian ini, maka yang dibutuhkan adalah deskripsi, gambaran, atau lukisan yang sistematis, faktual dan akurat dari persepsi pengguna atau stakeholder.Ini berarti bahwa hal yang dibutuhkan dalam penelitian ini adalah data atas pengetahuan / pemahaman termasuk kepuasan dari kelompok sasaran penelitian.

Sebagai konsekuensi dari metode yang dipakai, maka dalam penelitian ini, peneliti dituntut untuk menangkap sepenuhnya realitas empirik dari objek yang diteliti, yaitu persepsi pengguna luaranLembaga ini Fikom Unpad.

Pengguna luaran pendidikan menyangkut institusi pemerintah, Badan Usaha Milik Negara (BUMN), dan swasta.Selanjutnya para pimpinan ketiga institusi ini menjadi responden penelitian.

\section{Prosedur Pengumpulan Data}

Data diperoleh dari beberapa sumber yang berlainan dan dengan sifat data kebanyakan kualitatif. Sifat data ini seringkali menentukan instrumen dan teknik pengumpulan data itu sendiri. Yin mengidentifikasi enam teknik pengumpulan data yaitu: "dokumen, rekaman arsip, wawancara, observasi langsung, observasi pemeran serta, dan perangkat fisik (2002:103). Semenetara terkait dengan instrumen, Crotty, meng-identifikasi instrument penelitian khususnya dalam penelitian kualitatif juga dalam enam, yaitu Observation, Participant Observation, Interview , Focus group, Case study, Life history, $(1998 ; 5)$.
Berdasarkan beberapa pertimbangan yang dimiliki peneliti, maka dari sekian banyak prosedur pengumpulan data yang digunakan dalam penelitian ini hanya tiga yaitu :

\section{Wawancara Mendalam}

Observasi memang penting dalam sebuah penelitian kualitatif, akan tetapi teknik ini dinilai tidak memadai di dalam suatu penelitian, menurut Nasution hal ini disebabkan "Mengamati kegiatan dan kelakuan orang saja tidak dapat mengungkap apa yang diamati atau dirasakan orang lain. Itu sebabnya observasi harus dilengkapi oleh wawancara."(1992:69), karena itu dalam penelitian ini digunakan wawancara.

Wawancara menurut Yin (2002) bisa dikatagorikan dalam beberapa bentuk.Pertama open-ended, dimana peneliti dapat bertanya kepadarespondenkuncitentangfakta-fakta suatu peristiwa disamping opini mereka mengenai peristiwa yang ada.Kedua, wawancara terfokus, dimana responden diwawancarai dalam waktu yang pendek. Ketiga wawancara terstruktur, seperti halnya dalam survey.

Sementara itu, dilihat dari pendekatannya, wawancara menurut Nasution (1992) dibagi dalam tiga, yaitu :

1) Dalam bentuk pendekatan informal, yang mengandung unsur spontanitas, kesantaian, tanpa pola atau arah yang ditentukan sebelumnya

2) Menggunakan lembar berisi garis besar pokok-pokok, topic atau masalah yang dijadikan pegangan dalam pembicaraan

3) Menggunakan daftar pertanyaan yang lebih rinci, namun bersifat terbuka yang telah dipersiapkan lebih dahulu dan akan diajukan menurut urutan dan rumusan yang tercantum.

Dari tiga bentuk wawancara yang ada, yang dipakai dalam penelitian ini lebih pada bentuk yang ke tiga yaitu wawancara terstruktur. Sementara dilihat dari pendekatannya, yang dipakai dalam penelitian ini lebih pada pendekatan yang ketiga yaitu menggunakan daftar pertanyaan yang lebih rinci namun bersifat terbuka.

\section{Studi Pustaka dan dokumentasi}

Tipe informasi yang didapat dari studi pustaka atau dokumentasi dalam suatu penelitian 
memiliki arti penting. Manfaat yang diperoleh dari dokumentasi ini paling tidak menurut Yin (2002) ada tiga, yaitu : Pertama, dokumen membantu penverifikasian ejaan dan judul atau nama yang besar dari organisasi-organisasi yang telah disinggung dalam wawancara; kedua, dokumen dapat menambah rincian spesifik lainnya guna mendukung informasi dari sumber-sumber lain. Ketiga, inferensi dapat dibuat dari dokumendokumen.

Beberapa jenis dokumen yang menjadi rujukan dan pakai oleh peneliti menyangkut beberapa sumber seperti dikemukakan Yin, (2002) yaitu :

1) surat, pengumuman resmi;

2) agenda, kesimpulan pertemuan, serta laporan peristiwa tertulis;

3) dokumen administratif, laporan kemajuan;

4) hasil evaluasi resmi;

5) kliping ataupun artikel yang muncul di Koran.

Dari sederet pemikiran Yin, yang paling banyak digunakan dalam penelitian ini adalah hasil evaluai resmi, baik yang dilakukan institusi maupun mhasiwa sendiri.

\section{HASIL DAN PEMBAHASAN}

Tujuan dalam penelitian ini pada dasarnya adalah untuk mengetahui gambaran empirik mengenai persepsi pengguna luaran lembaga ini atas kompetensi seorang magister. Kompentensi yang dinilai pengguna atas luaran mencakup atas, integritas, profesionalisme luaran, kemampuan berbahasa asing, penggunaan teknologi komunikasi dan informasi, kemampuan berkomunikasi, kerjasama dalam tim, dan pengembangan diri.

\section{Persepsi penggunaluaran mengenai ke- mampuan Integritas (Etika dan Moral) luaran Lembaga ini}

Berdasarkan atas jawaban yang diberikan pengguna luaranmelalui angket atas aspek integritas (etika dan moral), hasilnya ditunjukan melalui diagram berikut :

\section{Moral dan Etika}

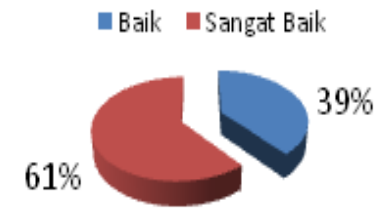

Gambar 1 Persepsi stakeholder (pengguna) luaran magister Ilmu Komunikasi Fikom Unpad atas aspek integritas (moral dan etika)

Gambar 1 menunjukkan kondisi dimana mayoritas luaran memiliki integritas yang sangat baik dilihat dari etika dan moral, yaitu sebesar $61 \%$. Sedangkan tanggapan pengguna luaran yang bahwa integritas luaran dilihat dari etika dan moral memiliki integritas yang baik, adalah sebesar 39\%.Berdasarkan data ini maka secara umum bisa dikatakan bahwa integritas luaran program ini dimata pengguna yang dilihat dari aspek etika dan moral luaran sudah sangat baik.

Dengan hasil seperti ini, bisa diasumsikan bahwa pengelola proses pendidikan di lembaga ini dinilai berhasil, dan memiliki andil yang besar dalam mencapai persepsi yang tinggi atas etika dan moral lulusan. Salah satu alasan yang jadi pijakan asumsi peneliti adalah moral dibentuk oleh kebiasaan, etos dan etik. Ini berarti bahwa etika dan moral yang menjadi pegangang lulusan adalah hasil pembiasaan.

Temuan penelitian ini menjadi modal bagi satuan penyelenggara pendidikan bahwatidak ada aktivitas pekerja yang melandaskan diri pada keutamaan moral (perbuatan baik) jika tidak dibiasakan berbuat baik (bermoral dan etis), dan salah satu tempat pembiasaan adalah lembaga pendidikan, artinya lembaga ini sudah melakukan pembiasaan berilaku dan bertindak etis di lingkungan proses belajar.

Beberapa alasan peneliti berasumsi bahwa penyelenggara pendidikan (Prodi Lembaga ini) berkontribusi bagi keberhasilan ini dilihat dari salahsatu tujuan pendidikan program magister yaitu menghasilkan luaran yang berdaya saing tinggi dan memiliki landasan moral, etika, dan tanggung jawab sosial yang baik. Alasan lain 
adalah program ini sudah memliki atau di dukung oleh adanya etika dosen, etika mahasiswa, etika tenaga pendidikan, sistem penghargaan dan sanksi serta pedoman dan prosedur pelayanan akademik Universitas Padjadjaran berdasarkan Surat Keputusan Rektor Universitas Padjadjaran Nomor: 379/J.06/KEP/KP/2004 tentang Pengesahan Etika Akademik dan Tata Laku Civitas Akademik dalam Penyelenggaraan Tri Dharma Perguruan Tinggi Universitas Padjadjaran.

2. Persepsi pengguna luaran mengenai keahlian berdasarkan bidang ilmu komunikasi (profesionalisme) luaran Lembaga ini

Berdasarkanatasjawaban yang diberikan stakeholder (pengguna) luaran Lembaga ini melalui angket atas aspek profesionalisme luaran saat saat ini, ditunjukan melalui diagram berikut

\section{Profesionalisme}

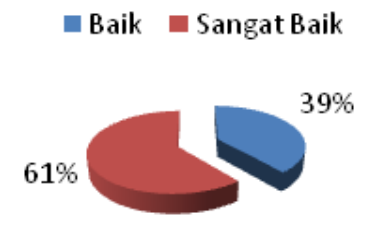

Gambar 2 Profesionalisme luaran Lembaga ini menurut pengguna

Berdasarkan data diatas menunjukkan mayoritas luaran Lembaga ini dinilai memiliki tingkat profesionalisme yang sangat baik dilihat dari keahlian di bidang komunikasi dan informasi. Sebesar 61\% dari responden atau pengguna menyatakan bahwa profesionalisme luaran dilihat dari keahlian dibidang komunikasi dan informasi dengan tingkat yang baik, sisanya sebesar 39\% memberi penilaian kurang.

Kondisi ini menunjukkan bahwa luaran Lembaga ini Fikom Unpad sebagian besar mampu menunjukan kemampuan yang baik di bidang komunikasi dan informasi. Kondisi ini juga sejalan dengan hasil penelitian Eriyanti (2012) kesimpulan yang diperoleh dari hasil wawancaranya adalah "luaran unpad memiliki keterampilan (skill) yang baik dan dapat diandalkan." (2012;179)

Dikaitkan dengan konsep kontek-inputproses-produk, maka bisa diartikan bahwa keluaran luaran Lembaga ini sudah mengalami proses pembelajaran yang mampu menjadikan keluaran lembaga ini miliki standar kemampuan dibidang yang digelutinya.

Hal lain yang bisa diartikan dari kondisi ini adalah pengelola program pascasarjana ilmu komunikasi Fikom Unpad mampu dan tepat melakukan penunjauan dalam mengembangkan program seperti yang dikatakan Conrad dan Wilson (1985), salah satunya mengenai "mutu, produktivitas, keperluan dan tuntutan".

Bagi Program studi lembaga ini, upaya pencapaian persepsi pengguna atas luaran seperti ini, di tunjukan melaluiu paya Lembaga ini Fikom Unpad dalam penetapan standar kompetensi dan luaran disesuaikan dengan kebutuhan dunia kerja teruatama di bidang ilmu komunikasi serta bekerjasama dengan berbagai asosiasi profesi yang ada dalam penentuan standar kompetensi dan profesionalisme luaran. Selain itu Lembaga ini Fikom Unpad juga mengaju pada standard kompetensi yang telah ditetapkan oleh ASPIKOM (Assosiasi Pendidikan Tinggi Ilmu Komunikasi).Persepsi penggunaluaran mengenai ke ahlian berbahasa asing luaran program magister ilmu komunkasi

Kemampuan berbahasa asing (inggris) merupakan salah satu kompetensi yang sangat penting saat ini, terlebih bila menyimak apa yang dikatakan Sobary dalam kompas terbitan tanggal 6 April 2008 bahwa mengenai kemandirian perguruan tinggi hingga "tak terekor oleh warna kulit yang lebih terang, tidak minder melihat dasi dan bahasa inggris yang fasih". Akan tetapi dalam era globalisasi yang sering diartikan sebagai masanya persaingan sekaligus persandingan (kerja sama), kemampuan berbahasa inggris menjadi hal esensial.

Jawaban yang diberikan pengguna luaran Lembaga ini melalui angket atas aspek kemampuan berbahasa asing, ditunjukan melalui diagram berikut :

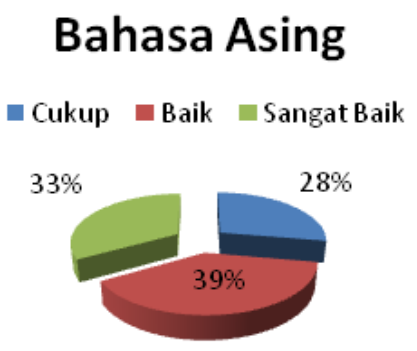

Gambar 3 Persepsi Pengguna atas kemampuan bahasa asing dari keluaran Lembaga ini 
Gambar 3 memperlihatkan kemampuan berbahasa asing dari luaran Lembaga ini terutama Bahasa Inggris. Kemampuan luaran prodi lembaga ini dalam bahasa asing yang berada pada tingkatan sangat baik sebesar $33 \%$, sedangkan tanggapan pengguna luaran terhadap kemampuan luaran dalam bahasa asing pada tingkatan baik, sebesar 39\%, dan yang beradapadatingkatancukupsebesar $28 \%$.

Data ini bisa diartikan bahwa pada dasarnya luaran program studi lembaga ini memiliki kemampuan bahasa inggris hanya saja kemampuannya bervariasi, mulai dari mereka yang sudah sangat fasih dalam percakapan dan benar secara tata bahasa, sampai pada mereka yang mengerti bahasa ingris namun pasif.

Kondisi seperti ini bisa dipahami mengingat salah satu bidang yang menjadi pertimbangan penerimaan menjadi mahasiswa pascasarjana atau program studi di lembaga ini adalah kemampuan bahasa inggris. Dalam seleksi yang dilakukan kemampuan bahasa khususnya Inggris diseleksi melalui Tes Kemampuan Bahasa (TKB).

Untuk meningkatkan kemampuan bahasa asing mahasiswa ataupun luaran Lembaga ini Fikom Unpad, Lembaga ini mulai tahun akademik 2012/2013 Semester tidak asal mewajibkan para calon luaran untuk menyertakan bukti kemampuan bahasa asing terutama Bahasa Inggris melalui sertifikat TOEFL dengan skor lebih dari 525.

\section{Persepsi pengguna luaran mengenai kemampuan penggunaan teknologi infor- masi luaran program studi lembaga ini}

Dryden dan Jeanenettte Vos mengatakan bahwa "Teknologi penyimpanan dan penyajian informasi telah berkembang luar biasa, memungkinkan orang untuk mengakses informasi secara instan dalam berbagai bentuk.Kemampuan tersebut merevolusi bisnis, pendidikan, kehidupan rumah tangga, manajemen, dan hampir segala sesuatu yang kita ketahui." (2000:39).

Pentingnya Teknologi Telekomunikasi Informasi (TTI) pada level internasional juga di tunjukan melalui rumusan UNESCO. Menurut UNESCO, pendidikan (TTI) dilakukan dengan bertujuan :

\section{Membangun Knowledge based socity} habits
2. mengembangkan keterampilan menggunakan TTI

3. Meningkatkan efisiensi \& Efektivitas

Berdasarkan pertimbangan ini maka penting kiranya kompetensi penggunaan teknologi komunikasi sebagai hal yang perlu ditanyakan kepada pengguna.

Berdasarkan atas jawaban yang diberikan pengguna luaran Lembaga ini melalui angket atas aspek profesionalisme yang dilihat dari aspek kemampuan menggunakan teknologi dan komunikasi dan informasi bagi luaran. ditunjukan melalui diagram berikut

\section{Penggunaan TI}

$$
\text { घ Baik } \quad \text { Sangat Baik }
$$

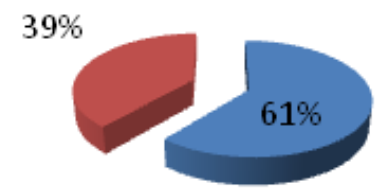

Gambar 4 Persepsi pengguna mengenai tingkat kemampuan penggunaan Teknologi Komunikasi dan Informasi menurut pengguna

Gambar 4 menunjukkan bahwa mayoritas luaran Lembaga ini memiliki tingkat kemampuan penggunaan teknologi informasi dengan katagori sangat baik (61 \%). Penilian ini dilihat dari aspek keahlian di bidang penggunaan teknologi komunikasi dan informasi. Sedangkan tanggapan pengguna luaran yang menyatakan bahwa tingkat kemampuan penggunaan teknologi informasi berada pada katagori baik, yaitu sebesar 39\%.

Ini berarti bahwa tingkat kemampuan penggunaan teknologi informasi luaran Lembaga ini Fikom Unpad di tempat kerja dilihat tanggapan pengguna luaran dapat disimpulkan telah memiliki kemampuan penggunaan teknologi informasi yang sangat tinggi.

Kondisi ini menunjukan bahwa sekalipun penguasaan teknologi komunikasi dan informasi tidak menjadi arah utama kompetensi yang ingin di bangung Lembaga Fikom Unpad akan tetapi sebagian besar luaran program ini dipersepsi punya kemampuan yang tinggi. Artinya, proses pembelajaran telah mendorong mahasiswanya untuk menguasai teknologi komunikasi tanpa harus diajarkan secara khusus atau dalam bentuk sebuah matakuliah. 
Sekalipun tidak menjadi rumusan kompetensi utama, bagi Lembaga ini penguasaan teknologi komunikasi dan informasi tetap di jadikan hal yang demikian penting dikaitkan dengan World Summit on the Information Society (WSIS) yang merupakan forum teknologi informasi dan komunikasi dunia di bawah badan PBB yaitu International Telecommunication Union (ITU), Tahun 2015telah dicanangkan beberapa rencana aksi sebagai berikut :

1. Menghubungkan Desa dengan Teknologi Informasi dan Komunikasi (TIK) dan membentuk Community Access Point;

2. Menghubungkan Universitas, Akademi, tingkat SMU dan SMP, tingkat SD, dengan Teknologi Informasi dan Komunikasi (TIK);

3. Menghubungkan Pusat Ilmu dan Penelitian dengan Teknologi Informasi dan Komunikasi (TIK);

4. Menghubungkan Perpustakaan Umum, Pusat Kebudayaan, Museum, Kantor Pos dan Kearsipan dengan Teknologi Informasi dan Komunikasi (TIK);

5. Menghubungkan Pusat Kesehatan dan Rumah Sakit dengan Teknologi Informasi dan Komunikasi (TIK);

6. Menghubungkan seluruh instansi pemerintah pusat dan daerah dan membuat website dan alamat e-mail;

7. Mengadopsi seluruh kurikulum sekolah dasar dan menengah dalam menghadapi tantangan masyarakat informasi, harus diperhitungkan pada taraf nasional;

8. Memastikan bahwa seluruh populasi di dunia mempunyai akses untuk pelayanan televisi dan radio;

9. Mendorong pengembangan konten dan menempatkan pada tempatnya kondisi secara teknis dalam rangka memfasilitasi keadaan terkini dan penggunaan semua bahasa di dunia di Internet;

10. Memastikan bahwa lebih dari setengah penduduk dunia mempunyai akses dengan Teknologi Informasi dan Komunikasi (TIK).

Menyadari hal ini Fikom Unpad melakukan pengembangan peningkatan kemampuan penggunaan teknologi informasi melalui penggunaan sistem informasi pada seluruh kegiatan akademik. Kebijakan ini juga telah mendorong para maha- siswa dan luaran lembaga pendidikan untuk terbiasa dan memiliki kemampun dalam berbagai penggunaan perangkat maupun aplikasi teknologi informasi dan komunikasi.

\section{Persepsi pengguna luaran mengenai kemampuan berkomunikasi luaran prog- ram studi lembaga ini}

John Dewey dalam Rivers, William L, dkk. Media Massa \& Masyarakat Modern berpendapat mengenai komunikasi yaitu "hal paling menakjubkan" dengan komunikasi manusia melakukan berbagai penyesuaian diri yang diperlukan. Jadi "manusia bertahan berkat adanya komunikasi, dan terus berkembang berkat komunikasi. (2004;33).

Menjadi hal yang tidak mengherankan jika banyak perguruan tinggi yang menetapkan kemamuan berkomunikasi sebagai salah satu kompetensi yang harus dimiliki oleh seluruh mahasiswanya.

Berdasarkan pemikiran ini dipandang perlu ditanyakan pada responden mengenai kemampuan berkomunikasi dari luaran Lembaga ini menurut pengguna. Hasil penyebaran angket atas kemampuan berkomunikasi, ditunjukan melalui gambar 5 berikut :

\section{Komunikasi}

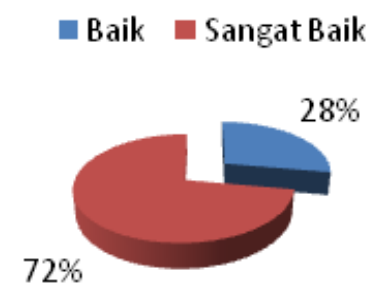

Gambar 5 kemampuan berkomunikasi luaran Lembaga ini menurut pengguna

Dalam Gambar 5.nampakbahwamayoritas (secara umum) luaran Lembaga ini memiliki tingkat kemampuan berkomunikasi yang sangat tinggi berdasarkan tanggapan dari para pengguna luaran, yaitu sebesar $72 \%$. Sedangkan tanggapan pengguna luaran yang menyatakan bahwa tingkat kemampuan berkomunikasi pada tingkatan baik, yaitu sebesar $28 \%$. Hal ini menunjukkan bahwa tingkat kemampuan berkomunikasi paraluaran Lembaga ini Fikom Unpad di tempat kerja dilihat tanggapan pengguna luaran terhadap keahlian komunikasi dapat disimpulkan memiliki kemampuan berkomunikasi yang sangat tinggi. 
Dikaitkan dengan data kemampuan pengunaan teknologi komunikasi dan informasi, terlihat jelas bahwa kemampuan berkomunikasi lebih tinggi. Kondisi ini menunjukan bahwa, arah orientasi utama program magister komunikasi tidak pada penguasaan teknologinya, melainkan lebih dikomunikasi sosial, hal ini terlihat betul jika dikaitkan dengan matakuliah yang diajarkan di Lembaga ini Fikom Unpad.

Berkomunikasi dengan baik tidak dimiliki oleh semua orang bahkan tidak sedikit manusia yang merasa diri bisa berkomunikasi akan tetapi ternyata dirinya tidak memiliki kemampuan berkomunikasi dengan baik. Contoh dalam memberi kritik tak jarang kita membenarkan kritik yang disampaikan seseorang bahkan kagum atas betapa bijaksananya si pengkritik dan kita berguman "iya,ya mengapa saya tidak memikirkan hal itu."Namun tidak jarang kita mendengar bahwa pihak yang dikritik tidak berubah, tidak bergerak atau bahkan sakit hati ?Ini membuktikan bahwa kritik tidak hanya perlu benar namun perlu juga disertai upaya bahwa yang dikritik menerima fakta tersebut dan menjadikan fakta tersebut menjadi miliknya.Jika kritik hanya menjadi fakta yang tetap dimiliki kita tanpa membuahkan action yang dikehendaki pada orang yang dikritik, sesungguhnya ini adalah bukti ketidakmampuan berkomunikasi secara efektif.

Kemampuan berkomunikasi mahasiswa pada program studi lembaga ini selain diberikan melalui perkuliahan di beberapa matakuliah seperti komunikasi antar pribadi, komunikasi kelompok, dan beberapa mata kuliah dasar ilmu komunikasi juga dikembangkan melalui penggunaan metode perkuliahan kelas dalam kemampuan mengungkapkan ide, pendapat dan gagasan. Peningkatan kemampuan komunikasi juga dibangun melalui interaksi dosenmahasiswa dalam kegiatan akademik yang bukan hanya dijumpai dalam proses pembelajaran di kelas, tetapi juga dapat dijumpai dalam kegiatan pene-litian, pengabdian kepada masyarakat maupun kegiatan non-akademik (ko-kurikuler/ ekstra-kurikuler, penalaran, dan lain-lain) yang bertujuan meningkatkan soft-skill mahasiswa. Untuk itu perguruan tinggi menfasilitasi semua kegiatan tersebut untuk menumbuhkan suasana omunikasijugadibangunmelaluiinteraksi dosen-mahasiswa dalam kegiatan akademik yang bukanhanya dijumpai dalam proses

\section{Persepsi penggunaluaran mengenai kemampuan bekerjasama dalam tim dari luaran program studi lembaga ini \\ Patrick S O'Brien dalam "making College} Count, mengidentifikasi tujuh (7) Soft Skill yang harus dimiliki oleh luaran perguruan tinggi, salah satu dari soft skill tersebut adalah terkait dengan kemampuan bekerja sama dalam satu tim.

Kemampuan bekerjasama dalam satu tim bagi luaran perguruan tinggi juga menjadi kompetensi yang harus dimiliki oleh luaran perguruan tinggi yang ada pada sepuluh negara maju. Ini menunjukan bahwa kemampuan atau kompetensi kerjasama dalam satu tim merupakan hal yang sangat penting dimiliki oleh luaran perguruan tinggi. Dan atas dasar pemikiran itu pula dalamriset ini dipandang penting untuk digali mengenai persepsi pengguna luaranLembaga ini mengenai kemampuan bekerjasama dalam satu timwork.

Hasil penyebaran angket mengenai ke mampuan kerjasama luaran program magister ditempat kerjanya ditunjukan melalui Gambar 6 seperti berikut :

\section{Kerjasama Tim}

\section{- Baik Sangat Baik}

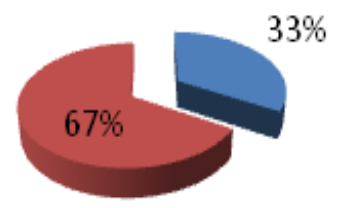

Gambar 6 Kemampuan kerjasama luaran Lembaga ini di tempat kerja

Gambar 6 di atas menunjukkan bahwa mayoritas luaran Lembaga ini memiliki tingkat kemampuan bekerja sama dalam tim yang sangat tinggi mencapai $67 \%$, sedangkan yang menyatakan baik sebanyak $33 \%$.

Mayoritas pengguna mempersepsi luaran lembaga ini mampu bekerjasama dalam tim yang sesungguhnya menjadi modal bagi luaran Lembaga ini dalam karir dan pengembangan dirinya di tempat kerja, hal ini sejalan dengan Mentkowski (1988) dan Loacker (1985) dalam Jordan bahwa kemampuan tersebut (salah satunya kerjasama dalam tim) sebagai dasar bagai pertumbuhan pribadi dan kinerja profesional kelak (1989:45). 
Berdasar pada logika ini, menjadi tidak mengherankan jika saat ini tidak sedikit luaranLembaga ini mampu mengembankan dirinya di tempat kerja sehingga menduduki jabatan, baik jabatan di lingkungan negeri maupun di swasta.

Upaya pencapaian kemampuan bekerja sama dalam tim di Lembaga ini diupayakan antara lain melalui proses pembelajaran di kelas sepert itugas kelompok maupun kerjasama tim, kegiatan lainnya yang mendorong kemampuan tersebut adalah melalui kegiatan penelitian, pengabdian kepada masyarakat dan manajemen sumberdaya yang mengoptimalkan pencapaian kompetensi ini.

\section{Persepsi pengguna luaran mengenai pengembangan diri}

Menurut Informasi \& teknologi literacy sebagai kunci pembelajaran abad 21, tugas lembaga pendidikan ialah membantu mereka untuk membentuksuatu framework for learning how to learn, ini berarti bahwa pendidikan memberi fondasi untuk tumbuh secara berkesinambungan sepanjang karir mereka, sekaligus dalam peran mereka sebagai informed citizens dan warga masyarakat.

Pemikiran ini pada akhirnya memberi gambaran bahwa pendidikan yang dilalui seorang individu dengan benar akan menjadi dasar bagi si pembelajar untuk secara terus menerus mengembangkan diri termasuk ketika mereka sudah bekerja (luaran dari sebuah perguruan tinggi). Dan atas pemikiran ini pula, dalam mengukur dampak pendidikan dari sebuah satuan pendidikan dinilai perlu bagaimana luaran tersebut mengembangkan dirinya ditempat kerja.

Hasil penyebaran angket pada pengguna mengenai pengembangan diri luaran Lembaga ini di tempat kerjanya ditunjukan dengan diagram sebagai berikut :

\section{Pengembangan Diri}
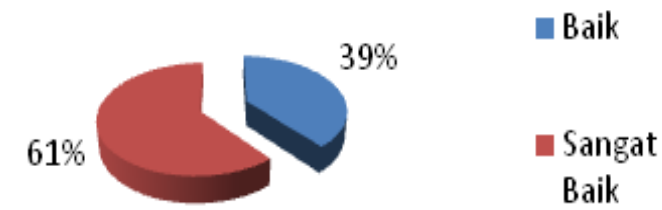

Gambar 7 Persepsi pengguna mengenai pengembangan diri luaran Lembaga ini
Gambar7 menunjukkan bahwa mayoritas luaran Lembaga ini memiliki kemampuan pengembangan diri yang sangat tinggi sebesar $61 \%$. Sedangkan tanggapan pengguna luaran yang menyatakan bahwa luaran Lembaga ini tingkat kemampuan pengembangan diri yang baik adalah sebesar 39\%.

Data ini bisa diartikan bahwa kebanyakan luaran Lembaga ini mampu belajar secara terus menerus, atau kebanykan menjadikan apa yang dilakukannya sebagai sebuah pembelajaran bagi dirinya.

Kondisi ini bisa diartikan bahwa proses pendidikan di Lembaga ini meletakan kesadaran mengenai pendidikan berkelanjutan (continuing education) bagi luarannya, yaitu kegiatan pendidikan yang dapatmemperbaiki dan meningkatkan pengetahuan dan keterampilan serta profesi untuk dijadikan fasilitas dalam peningkatan diri dan produktivitas kertja,(Unesco,1987).

\section{SIMPULAN}

Berdasar pada tujuan penelitian, landasanlandasan pemikiran dan hasil analisa atas data yang dihimpun, pada akhirnya dari penelitian ini ada beberapa pemikiran yang bisa dijadikan sebagai kesimpulan akhir, yaitu :

1) Menurut pengguna, luaranLembaga ini, dipersepsi sebagai tenaga kerja yang memiliki integritas yang baik.

2) Pengguna luaranlembaga ini dinilai memiliki tingkat profesionalisme yang sangat tinggi dalam bidang komunikasi

3) Pengguna luaran Lembaga ini dipersepsi sebagai orang yang memiliki kemampuan bahasa asing yang cukup baik.

4) Sebagian besar, luaran lembaga ini dipersepsi sebagai orang yang memiliki tingkat kemampuan menggunakan teknologi komunikasi dan informasi yang sangat baik.

5) Mayoritas luaran lembaga ini dipersepsi pengguna sebagai output perguruan tinggi yang memiliki tingkat kemampuan berkomunikasi di lingkungan kerja yang baik.

6) Sebagian besar pengguna luaran Lembaga inisebagai tenaga kerja yang memiliki tingkat kemampuan bekerjasama dalam tim yang tinggi.

7) Sebagian besar pengguna luaran Lembaga ini mempersepsi luaran lembaga ini sebagai pegawai yang memiliki kemampuan pengembangan diri yang tinggi. 


\section{Saran}

Berdasarkan atas kesimpulan yang diperoleh melalui penelitian, pada akhirnya ada beberapa pemikiran untuk menjadi bahan pertimbangan pengelola penyelenggara pendidikan Lembaga ini, yaitu ;

1) Kebutuhan pengguna luaran perguruan tinggi sudah terspesialisasi dengan tegas dan senantiasa berubah, oleh karenanya kerja sama yang berkelanjutan antara penyelenggara Lembaga ini dengan pengguna menjadi keharusan.

2) Untuk mencapai relevansi keluaran Lembaga ini yang lebih tinggi dengan dunia kerja tanpa harus menambah beban kridit semester mahasiswa, disarankan agar frekuensi dosen tamu dari kalangan praktisi ditingkatkan.

\section{DAFTAR PUSTAKA}

Buchori, M (1994). Spektrum Problematika Pendidikan di Indoensia, Yogyakarta, Tiara Wacana

Creswell, J.W (1994). Research Design Qualitative \& Quantitaive Approaches, California, Sage Publicationa Inc
Fitz-enz, J. (2000). The ROI of Human Capital, American Management Association, New York

Jordan, Thomas (1989). Measurement \& Evaluation In Higer Education, The Falmer Press, Philadelphia

Miarso, Y. (2005). Menyemai Benih Teknologi Pendidikan, Jakarta, Prenada Media

Owens, Robert (1984). Organizational Behavior in Education, Simon \& Scuster Company, Florida

\section{Sumber Lain :}

Eriyanti, 2012, Strategi Public Relations Unpad Menuju Internasionalisasi Perguruan Tinggi, (Tesis)

Kompas, 6 April 2008

Kompas tanggal 25 Mei 1999

Mimbar Pendidikan no 4

Tahun XIV, 1995

Rahmat, 2008, Pengembangan Model Pembelajaran Melalui Radio Komunitas untuk Pemberdayaan Petani di Wilayah Transmigrasi Lokal Kabupaten Sumedang 